\title{
The Implementation of Physical Fitness Learning Module in Kindergarten
}

\author{
K.R. Adhe, F.D. Khory \& T. Harianto ${ }^{\mathrm{a}, 1}$, M.A. Al Ardha, C.B. Yang \& K.P. Putra ${ }^{\mathrm{b}, 2}$ \\ aUniversitas Negeri Surabaya, Surabaya, Indonesia \\ bNational Dong Hwa University, Taiwan \\ ardha_sport@yahoo.com
}

\begin{abstract}
The Physical education in early childhood could provide more chances for student to develop their physical ability and motoric development by a variety of physical exercise. This research aims to develop an ideal lesson plan of physical education which is suitable and worthwhile for early childhood student to develop their physical fitness. The research involved 20 kindergarten students (Age \pm 6 years old) in to 6 times physical education meetings that was conducted using Dick and Carey systematic approach. There are three research instruments that were used in this study, which are one leg stand in balance test, horizontal jump in power test, and hopscotch performance in coordination test. As the result, there are significant difference between pretest and posttest (significant value $<0.05 \%$ ) in every dependent variable. In conclusion, the implementation of such instructions to increase early childhood physical fitness components worked effectively. The instructional objectives were accomplished completely and significantly.
\end{abstract}

\section{Keywords_- physical education; early childhood; kindergarten}

\section{INTRODUCTION}

The introduction chapter will explain the facts and conditions of the issues that attracted the researcher to conduct this study; the discussion will be divided into five sections as follows: background of the study, purpose of the study, research questions, definition of terms, significance of the study and research limitation. Early childhood education is a unique phase of education that has unique characteristic of the learner and the way they learn. It requires the educators to provide them with a good and appropriate instructional design. Facilitating their learning process helps them in every dimension of growth and development. It is very critical for the educators as the learners in early childhood education is in the golden age of growing and development. In physical fitness for example, kids improve their physical fitness such as coordination, balance, strength, muscle endurance, flexibility, cardiovascular system and nerve by repeating activities in playing a game.

The improvement of physical fitness during childhood is very important, because it is a basic of body component ability that could support them to master specific sport skills in the future. The frequency and accuracy of practicing this physical fitness is an issue, because in Indonesia early childhood education commonly does not provide physical education classes for their students. It is because of many factors, which two of them are the government regulation and school recourses.

Indonesian government does not have any physical education curriculum especially for childhood education, so the school does not get any support from the government to give such lesson to their students. In addition, early childhood has limitation in the human recourses. Early childhood education teachers usually do not pursue any specific education or training about physical activity and exercise, so they do not have enough idea to run a physical education class. It becomes an issue especially when we consider about their student needs of very specific and careful treatment to avoid some disadvantages from physical activities and exercises.

However, it is very important to have physical education in early childhood, because it provides more chances for students to practice and develop their ability through a variety of physical exercise. The physical education in the golden age is a perfect attempt to reach the best benefit. It is because the physical education will give benefits not only for their physical and motoric development but also for their social, emotional and cognitive development.

\section{METHOD}

\section{A. Research Design}

This research was conducted using Dick and Carey systematic approach which has 10 steps to follow. However, this research has no summative test at the end of the study [1].

\section{B. Research Participants}

The participants of this study were 20 students of UNESA Kindergarten Laboratory Surabaya, Indonesia. The students are 6 years old and study in the same grade.

\section{Research Procedure}

The research was conducted in approximately 6 meetings, because the treatment of each physical fitness component was applied for two meetings which were pretest in the first meeting and posttest in the second meeting. The complete procedures are written in the Chapter 6: Lesson Plan and Chapter 7: Instructional Contents.

\section{Research Instruments}

There are three research instruments that will be used in this study, which are one leg stand in balance test, horizontal 
jump in power test, and hopscotch performance in coordination test (Chapter 5: Test Items).

\section{E. Data Analysis}

The data will be translated into ordinal data which has ratio 1:4. Furthermore, the data will be tested through dependent $t-$ test using SPSS 20.0 software to determine the difference between pretest and posttest scores.

\section{RESULT AND DISCUSSIONS}

Data analysis of this study has three main parts which are students' performance achievement, students' feedback, and physical education instructor observation form. All of those data are recorded and summarized as follows:

\section{A. Performance Achievement}

Here are three items in the students' performance achievement data in which each item has pretest and posttest data. The following table is a descriptive statistic from the whole data of students' performance achievement which was analyzed using SPSS 20.0 Software:

TABLE I. DESCRIPTIVE STATISTICS OF STUDENTS' PERFORMANCE ACHIEVEMENT

\begin{tabular}{|l|r|r|r|r|r|r|}
\hline & \multicolumn{1}{|c|}{ N } & Minimum & Maximum & Sum & Mean & $\begin{array}{c}\text { Std. } \\
\text { Deviation }\end{array}$ \\
\hline PPrT & 19 & 2 & 4 & 53 & 2.79 & .713 \\
\hline PPoT & 19 & 2 & 4 & 65 & 3.42 & .607 \\
\hline BPrT & 19 & 1 & 4 & 58 & 3.05 & .705 \\
\hline BPoT & 19 & 3 & 4 & 72 & 3.79 & .419 \\
\hline CPrT & 18 & 1 & 4 & 64 & 3.56 & .784 \\
\hline CPoT & 18 & 2 & 4 & 68 & 3.78 & .548 \\
\hline $\begin{array}{l}\text { Valid N } \\
\text { (listwise) }\end{array}$ & 18 & & & & & \\
\hline
\end{tabular}

The data shows that every item has an increment in the post test mean. For example in power test result, the mean of power test post test (PPoT) 3.42 is higer than the mean of power test pretest (PPrT) 2.79. In the balance test, the post test score (BPoT) is 3.79 and the pretest score (BPrT) is 3.05. Besides, the coordination score post test $(\mathrm{CPoT})$ is 3.78 and the pretest (CPrT) is 3.56 .

TABLE II. DEPENDENT T-TEST OF BALANCE TEST

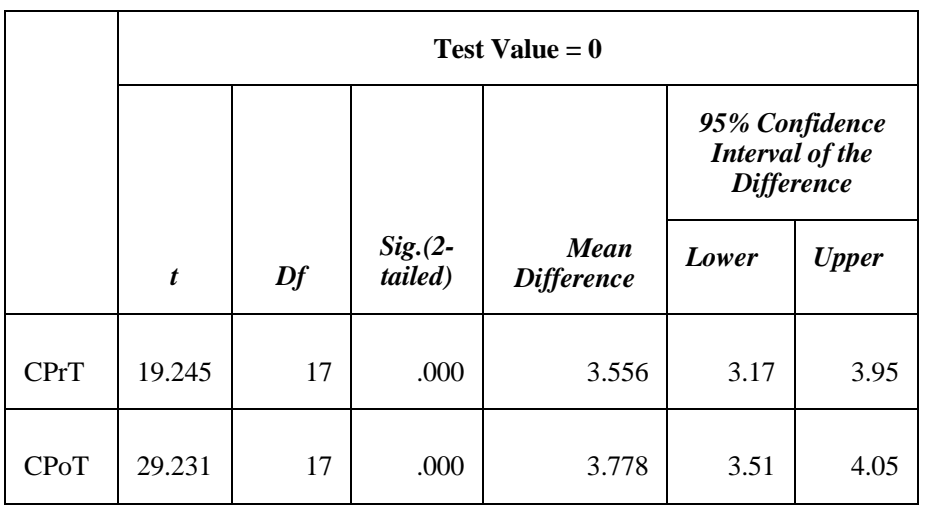

TABLE III. DEPENDENT T-TEST OF BALANCE TEST

\begin{tabular}{|c|c|c|c|c|c|c|}
\hline & \multicolumn{6}{|c|}{ Test Value $=0$} \\
\hline & \multirow[b]{2}{*}{$t$} & \multirow[b]{2}{*}{$d f$} & \multirow[b]{2}{*}{$\begin{array}{l}\text { Sig.(2- } \\
\text { tailed) }\end{array}$} & \multirow[b]{2}{*}{$\begin{array}{r}\text { Mean } \\
\text { Difference }\end{array}$} & \multicolumn{2}{|c|}{$\begin{array}{l}\text { 95\% Confidence } \\
\text { Interval of the } \\
\text { Difference }\end{array}$} \\
\hline & & & & & Lower & Upper \\
\hline CPrT & 18.873 & 18 & .000 & 3.053 & 2.71 & 3.39 \\
\hline CPoT & 39.436 & 18 & .000 & 3.789 & 3.59 & 3.99 \\
\hline
\end{tabular}

\section{CONCLUSION}

The implementation of instructional system design especially Dick, Carey and Carey Model to increase early childhood physical fitness components worked effectively. The instructional objectives were completely accomplished. It could be seen from the increase of students' ability in all physical fitness components that were conducted.

This study is a pioneer study to develop physical education curriculum in Indonesia. For future research, it is important to conduct related research which involves more subjects and various variables to be observed. Some implications from this study that may be considered for the next research are about the duration of study, research variables, and unpredicted variables. It may be interesting to use another research approach or mix-method, because more views that we use could give more possible data and findings to create the best physical education curriculum.

\section{REFERENCES}

[1] A. Burggraff, Developing Discipleship Curriculum: Applying The Systems Approach Model for Designing Instruction by Dick, Carey, and Carey To The Construction Of Church Discipleship Courses, 2015.

[2] Bob. Carroll, Assessment in Physical Education: A Teacher's Guide to the Issues. Bristol, USA: The Falmer Press, 2005.

[3] G. B. DeHart, L. A. Sroufe, and R. G. Cooper, Child Development, USA: McGraw-Hill, 2004.

[4] B. D. Franks, and H. Deutsch, Evaluating Performance in Physical Education. New York, USA: Academic Press, 1973.

[5] B. Hopper, J. Grey, and T. Maude, Teaching Physical Education in the Primary School. New York, USA: RoutledgeFalmer, 2005.

[6] A. Laker, Beyond the Boundaries of Physical Education: Educating Young People for Citizenship and Social Responsibility. New York, USA: Routledge Falmer, 2001.

[7] E. Krakow, Physical Activity in Early Childhood: Settting the Stage for Lifelong Healthy Habits, Parenting Series, The Lawson Foundation, April 2011.

[8] M. Rathbone, Health and Physical Education, kindergarten $-12^{\text {th }}$ grade, Washington State Learning Standards, Washington: Office of Superintendent of Public Instruction, 2016.

[9] Daily Physical Activity in Schools, grade 1 to 3, Resource Guide, Ontario Education, 2005.

[10] Metzler, Michael. Instructional models in physical education. Taylor \& Francis, 2017. 
[11] D.P. Coe, J.M. Pivarnik, C.J. Womack, M.J. Reeves, and R.M. Malina, Effect of physical education and activity levels on academic achievement in children. Medicine \& Science in Sports \& Exercise, 38(8), pp.1515-1519, 2006.

[12] M. Mosston, and S. Ashworth, Teaching physical education, 2002.

[13] F. Trudeau, and R.J. Shephard, "Physical education, school physical activity, school sports and academic performance," International
Journal of Behavioral Nutrition and Physical Activity, vol.5 no. 1, pp. 10, 2008.

[14] D.L. Gallahue, and F.C. Donnelly, Developmental physical education for all children. Human Kinetics, 2007.

[15] U. Pühse, and M. Gerber, eds., International comparison of physical education: concepts, problems, prospects. Meyer \& Meyer Verlag, 2005. 